\title{
Detection of reactive nitrogen containing particles in the tropopause region - evidence for a tropical nitric acid trihydrate (NAT) belt
}

\author{
C. Voigt ${ }^{1}$, H. Schlager ${ }^{1}$, A. Roiger ${ }^{1}$, A. Stenke ${ }^{1}$, M. de Reus ${ }^{2}$, S. Borrmann ${ }^{2,3}$, E. Jensen ${ }^{4}$, C. Schiller ${ }^{5}$, P. Konopka ${ }^{5}$, \\ and N. Sitnikov ${ }^{6}$ \\ ${ }^{1}$ Deutsches Zentrum für Luft- und Raumfahrt, Institut für Physik der Atmosphäre, Oberpfaffenhofen, Germany \\ ${ }^{2}$ Institut für Physik der Atmosphäre, Universität Mainz, Germany \\ ${ }^{3}$ Max-Planck-Institut für Chemie, Abteilung Wolkenphysik, Mainz, Germany \\ ${ }^{4}$ NASA Ames Research Center, Moffett Field, CA, USA \\ ${ }^{5}$ Institut für Chemie und Dynamik der Geosphäre, FZ Jülich, Germany \\ ${ }^{6}$ Central Aerological Observatory, Moscow, Soviet Union
}

Received: 20 June 2008 - Published in Atmos. Chem. Phys. Discuss.: 23 July 2008

Revised: 24 November 2008 - Accepted: 24 November 2008 - Published: 15 December 2008

\begin{abstract}
The detection of nitric acid trihydrate (NAT, $\mathrm{HNO}_{3} \times 3 \mathrm{H}_{2} \mathrm{O}$ ) particles in the tropical transition layer (TTL) harmonizes our understanding of polar stratospheric cloud formation. Large reactive nitrogen $\left(\mathrm{NO}_{\mathrm{y}}\right)$ containing particles were observed on 8 August 2006 by instruments onboard the high altitude research aircraft M55-Geophysica near and below the tropical tropopause. The particles, most likely NAT, have diameters less than $6 \mu \mathrm{m}$ and concentrations below $10^{-4} \mathrm{~cm}^{-3}$. The NAT particle layer was repeatedly detected at altitudes between 15.1 and $17.5 \mathrm{~km}$ over extended areas of 9.5 to $17.2^{\circ} \mathrm{N}$ and $1.5^{\circ} \mathrm{W}$ to $2.7^{\circ} \mathrm{E}$ above the African continent. Satellite observations suggest that the NAT particles could have nucleated on ice fed by convective activity. Once nucleated, the NAT particles can slowly grow within the TTL for days, while being transported over long distances. Their in-situ detection combined with global model simulations of the NAT supersaturation near the tropical tropopause indicate the potential for a tropical tropopause NAT particle belt.
\end{abstract}

\section{Introduction}

The composition of the tropopause region is modified by ice crystals and $\mathrm{HNO}_{3}$ containing aerosol through uptake of wa- ter $\left(\mathrm{H}_{2} \mathrm{O}\right)$ and nitric acid $\left(\mathrm{HNO}_{3}\right)$ (Voigt et al., 2006) with subsequent particle sedimentation. Processing of nitrogen and halogen species as well as hydroperoxy radicals (Borrmann et al., 1996) on cirrus clouds and cold aerosol can affect the ozone budget of the tropopause region. Still the role of ice crystals and other solid particles in the tropopause region, their nucleation mechanism and the related questions whether they could dehydrate or even hydrate the lowermost stratosphere above convective systems remains elusive.

Although the thermodynamical possibility of the existence of solid nitric acid aerosol in the tropical tropopause layer has early been proposed by Hamill and Fiocco (1988), the observational evidence was missing for almost two decades. In fact, only recently Popp et al. (2006) detected NAT particles in the tropical lowermost stratosphere south of Costa Rica with an aircraft-borne particle mass spectrometer. One of the reasons for the gap between prediction and observation of NAT particles in the tropopause region is the low nitric acid content of tropical NAT clouds of a few pptv $\mathrm{HNO}_{3}$, which makes their detection from space difficult (Jensen and Drdla, 2002). Nevertheless, attempts have been made to identify tropical NAT clouds from HALOE extinction data (Herwig and McHugh, 2002) and to relate their presence to regions with frequent occurrence of lightning and in consequence to regions with enhanced concentrations of reactive nitrogen species (Chepfer et al., 2007).

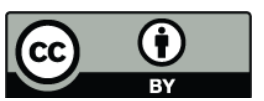

Correspondence to: C. Voigt

(christiane.voigt@dlr.de)

Published by Copernicus Publications on behalf of the European Geosciences Union. 


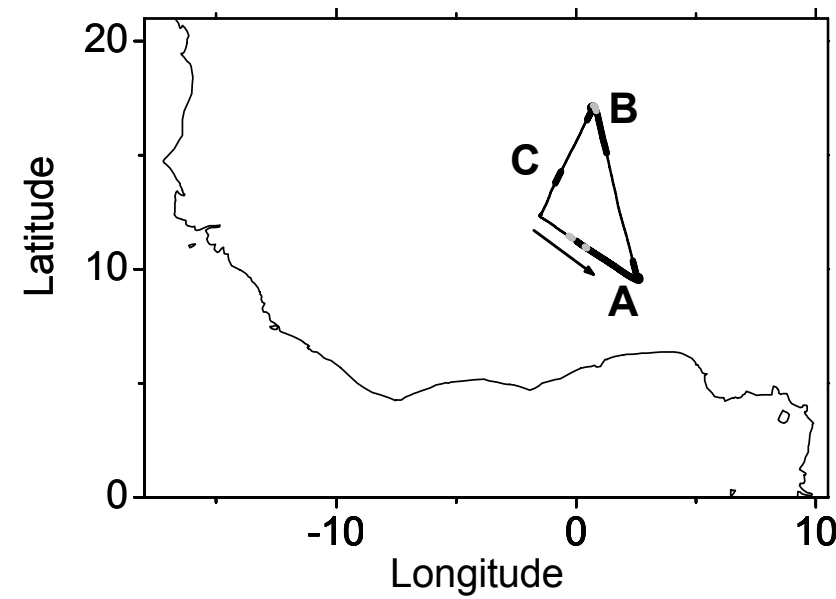

Fig. 1. Fight track of the M55-Geophysica over Africa on 8 August 2006. The arrow shows the flight direction. The thick black lines indicate regions with NAT particle observations, the thick gray line observations of cirrus clouds.

In addition, the detection of NAT clouds is frequently masked by the presence of cirrus clouds in the tropics. Near the tropical tropopause NAT is stable at conditions about $2 \mathrm{~K}$ above the ice frostpoint $T_{\text {ICE }}$, hence there exists only a small temperature window for the detection of pure NAT clouds (Popp et al., 2007). Cold tropical cirrus clouds have been shown to contain enhanced concentrations of $\mathrm{HNO}_{3}$ (Voigt et al., 2007; Popp et al., 2007) at temperatures below the NAT saturation threshold $(T<205 \mathrm{~K})$, promoting the formation of NAT clusters on ice (Gao et al., 2004). Despite theoretical and observational efforts, the nucleation process of solid $\mathrm{HNO}_{3}$ containing particles in the tropical tropopause region - as well as in the polar stratosphere - remains puzzling.

In the present study, we investigate a cold region of NAT supersaturated air near and below the tropical tropopause. Besides measurements of $\mathrm{H}_{2} \mathrm{O}$ and particles, reactive nitrogen species $\left(\mathrm{NO}_{\mathrm{y}}=\mathrm{HNO}_{3}+\mathrm{NO}+\mathrm{NO}_{2}+\mathrm{N}_{2} \mathrm{O}_{5}+\mathrm{PAN}+\ldots\right)$ have been observed in the gas phase and in particles. Recently Popp et al. (2006) detected NAT particles in the tropical lowermost stratosphere south of Costa Rica. In this work, we present first evidence for the presence of NAT particles in the tropical transition layer over the African continent. We show chemical, microphysical and optical observations of $\mathrm{NO}_{\mathrm{y}}$ containing particles in the tropical tropopause region that were - based on the available observational evidence present in the form of NAT and discuss their growth and nucleation process. The measurements were performed on 8 August 2006 with the high altitude research aircraft M55Geophysica during the African Monsoon Multidisciplinary Analysis (SCOUT-O3/AMMA) from Ouagadougou, Burkina Faso.

\section{Instrumentation}

The $\mathrm{NO}_{\mathrm{y}}$ instrument SIOUX is described in detail in Voigt et al. (2005). On most of the flights during the AMMA campaign, it was configured to detect gaseous $\mathrm{NO}_{\mathrm{y}, \mathrm{g}}$ and nitric oxide (NO). In contrast, on 8 August 2006 total reactive nitrogen $\left(\mathrm{NO}_{\mathrm{y}, \mathrm{t}}\right.$, that is the sum of gaseous and enhanced particulate $\mathrm{NO}_{\mathrm{y}}$ ) and $\mathrm{NO}$ were measured with forward and backward facing inlets of the $\mathrm{NO}_{\mathrm{y}}$ instrument. In brief, the detection principle of the $\mathrm{NO}_{\mathrm{y}}$ instrument is based on the evaporation of particles in the forward facing inlet, the reduction of gaseous $\mathrm{NO}_{\mathrm{y}}$ to $\mathrm{NO}$ with $\mathrm{CO}$ in a heated gold converter and the detection of the chemiluminescence reaction of $\mathrm{NO}$ with ozone.

Near the tropical tropopause the $\mathrm{NO}_{2}$ mixing ratio is about a factor of 6 smaller than the NO mixing ratio (Jensen and Drdla, 2002). Hence an upper limit of the total enhanced $\mathrm{HNO}_{3, \mathrm{t}}$ mixing ratio can be derived by subtracting the calculated $\mathrm{NO}_{\mathrm{x}}\left(=\mathrm{NO}+\mathrm{NO}_{2}=1.16 \times \mathrm{NO}\right)$ from the $\mathrm{NO}_{\mathrm{y}, \mathrm{t}}$ mixing ratio. Thereby we neglect e.g. the contribution of other $\mathrm{NO}_{y}$ species such as PAN to the $\mathrm{NO}_{\mathrm{y}}$ concentration near the tropical tropopause.

The instrumental error for $\mathrm{NO}_{\mathrm{y}, \mathrm{t}}$ is $\pm 12 \%$ and for $\mathrm{NO}$ it is $10 \%$. As the particle velocity in the inlet is smaller than the aircraft velocity, the detected particle concentrations are enhanced relative to ambient values. When particle concentrations are low enough $\left(\leq 10^{-3} \mathrm{~cm}^{-3}\right)$, individual large $(\mathrm{d}>1.8 \mu \mathrm{m})$ reactive nitrogen containing particles can be detected as peaks above the background gas phase signal. The frequency of these peaks and the known sampling volume directly yield the ambient particle concentration.

Gas phase $\mathrm{H}_{2} \mathrm{O}_{\mathrm{g}}$ and total $\mathrm{H}_{2} \mathrm{O}_{\mathrm{t}}\left(\mathrm{H}_{2} \mathrm{O}_{\mathrm{g}}\right.$ plus enhanced particle $\mathrm{H}_{2} \mathrm{O}$ ) were measured with two independent Lyman- $\alpha$ hygrometers. The gas phase instrument FLASH measures $\mathrm{H}_{2} \mathrm{O}_{\mathrm{g}}$ with a rear facing inlet with an accuracy of $10 \%$. The accuracy of the total water instrument FISH (Schiller et al., 1999 ) is $8 \%$ in regions without particle observations. The detection limit for the ice water content (IWC) in cirrus clouds depends on temperature and is $0.3 \mathrm{ppmv}$ below $205 \mathrm{~K}$. The temperature was measured with an accuracy of $\pm 0.6 \mathrm{~K}$ with a Rosemount sensor.

We calculate the frostpoint $T_{\mathrm{ICE}}$ and the ice saturation ratio $S_{\text {ICE }}$, that is the $\mathrm{H}_{2} \mathrm{O}$ vapor pressure divided by the $\mathrm{H}_{2} \mathrm{O}$ partial pressure over ice (Marti and Mauersberger, 1993) from the FLASH $\mathrm{H}_{2} \mathrm{O}_{\mathrm{g}}$ measurements. For time periods when the gas phase instrument was not active, we calculate $T_{\text {ICE }}$ outside of ice clouds (as identified by correlated increases in the FSSP and the FISH signal) from the FISH data.

Particle size distribution and number density were detected with a forward scattering spectrometer probe (Borrmann et al., 2000). The FSSP100 detects light scattered by particles in the diameter range $2.7-29.7 \mu \mathrm{m}$. The detection of only 1 particle within $100 \mathrm{~s}$ by the FSSP corresponds to an ambient particle concentration $1.1 \times 10^{-4} \mathrm{~cm}^{-3}$. The error in particle number density from the FSSP data is dominated by the 


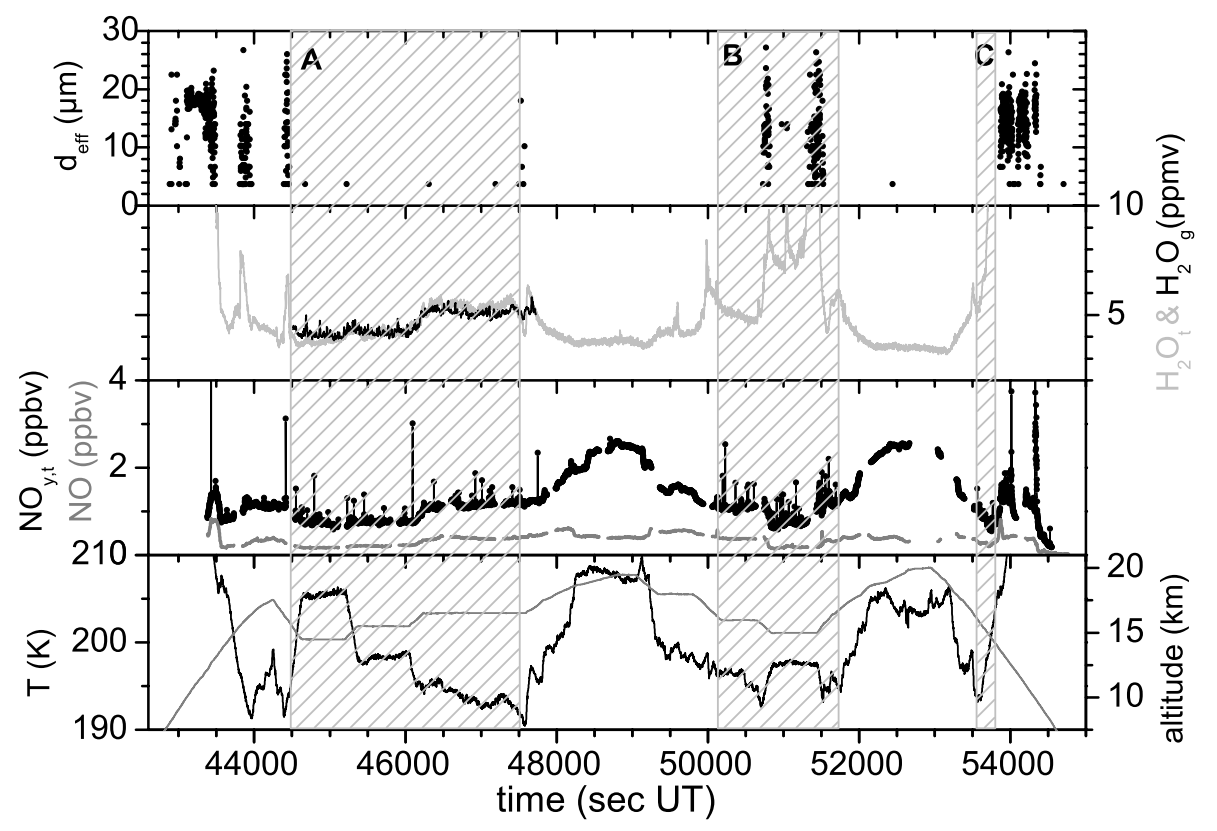

Fig. 2. Time series of effective particle diameters, total $\mathrm{H}_{2} \mathrm{O}_{\mathrm{t}}$ and gasphase $\mathrm{H}_{2} \mathrm{O}_{\mathrm{g}}$, total $\mathrm{NO}_{\mathrm{y}, \mathrm{t}}, \mathrm{NO}, T$, and altitude measured on 8 August 2006 above Africa. Spikes in the $\mathrm{NO}_{\mathrm{y}}$ signal indicate the presence of $\mathrm{NO}_{\mathrm{y}}$ containing particles as marked by the shaded areas. $\mathrm{NO}_{\mathrm{y}, \mathrm{t}}$ and $\mathrm{H}_{2} \mathrm{O}_{\mathrm{t}}$ data are not corrected for particle enhancement.

error due to counting statistics, which is equal to the square root of the number of particles measured in a specific time period. Hence, for 1 particle the error is $100 \%$, for 4 it decreases to $50 \%$. The uncertainty in the sampling volume of $25 \%$ plays a minor role.

\section{Particle observations near and below the tropical tropopause}

$\mathrm{NO}_{\mathrm{y}}$ containing particles were observed on 8 August 2006 above the West African continent (Burkina Faso, Benin and Mali) between 9.5 to $17.2^{\circ} \mathrm{N}$ and $1.5^{\circ} \mathrm{W}$ to $2.7^{\circ} \mathrm{E}$ as indicated by the thick black line on the flight path in Fig. 1. Time series of the particle observations and meteorological data are shown in Fig. 2. Individual $\mathrm{NO}_{\mathrm{y}}$ containing particles are identified as peaks in the $\mathrm{NO}_{\mathrm{y}, \mathrm{t}}$ signal. These individual $\mathrm{NO}_{\mathrm{y}, \mathrm{t}}$ peaks were observed in flight segments A (44537 to $47749 \mathrm{~s} \mathrm{UT}$ ), B (50 194 to $51691 \mathrm{~s} \mathrm{UT}$ ) and C (53 563 to $53765 \mathrm{~s} \mathrm{UT}$ ) for 54, 25 and $3 \mathrm{~min}$ and over distances of 542, 249 and $27 \mathrm{~km}$. Overall, 88 particles were detected continuously while measuring at altitudes between 15.1 and $17.5 \mathrm{~km}$, near the thermal tropopause intermittently over a broad geographic extent $(818 \mathrm{~km})$. The thermal tropopause was located between 16.2 and $17 \mathrm{~km}$ altitude, as derived from the temperature data of the Rosemount sensor onboard the Geophysica. The absence of particle peaks in the $\mathrm{NO}_{\mathrm{y}, \mathrm{t}}$ signal in the stratosphere at altitudes above $17.5 \mathrm{~km}$ confirms that $\mathrm{NO}_{\mathrm{y}}$ peaks are not related to an instrument malfunction. During flight segment $\mathrm{A}, 44 \mathrm{NO}_{\mathrm{y}}$ containing particles were observed,
36 particles were detected in flight segment $\mathrm{B}$, while $8 \mathrm{NO}_{\mathrm{y}}$ containing particles were measured in flight segment $\mathrm{C}$. In total, the observation of 88 particles yield an average particle concentration of $3 \times 10^{-5} \mathrm{~cm}^{-3}$ along the $818 \mathrm{~km}$ sampling track. We suggest that higher concentrations of smaller $\mathrm{NO}_{\mathrm{y}}$ containing particles could be present, which cannot be identified as peaks in the $\mathrm{NO}_{\mathrm{y}, \mathrm{t}}$ signal due to their low $\mathrm{HNO}_{3}$ content.

Patches of ice clouds were embedded in the extended $\mathrm{NO}_{\mathrm{y}}$ containing particle layer. Contrarily to the $\mathrm{NO}_{\mathrm{y}}$ particles, the cirrus clouds were identified by a correlated increase in the $\mathrm{H}_{2} \mathrm{O}_{\mathrm{t}}$ data measured by the FISH hygrometer, the particle number density detected by the FSSP and the $\mathrm{NO}_{\mathrm{y}, \mathrm{t}}$ signal of the $\mathrm{NO}_{\mathrm{y}}$ instrument. Ice clouds were present whenever ice saturation $S_{\text {ICE }}$ exceeded 1. Cirrus clouds were observed at altitudes between 10.3 and $14.3 \mathrm{~km}$ during ascent and descent. In addition patches of cirrus clouds were detected on the top and intermittently within the $\mathrm{NO}_{\mathrm{y}}$ containing particle layer, in total four times between 43809 to $43965 \mathrm{~s}$ UT (16.1 to $16.9 \mathrm{~km}, 156 \mathrm{~s}$ ), 44392 to $44461 \mathrm{~s} \mathrm{UT}$ ( 16.8 to $16.4 \mathrm{~km}$, $69 \mathrm{~s}), 50728$ to $50817 \mathrm{~s} \mathrm{UT}(16.1$ to $15.7 \mathrm{~km}, 89 \mathrm{~s})$, and 51311 to $51527 \mathrm{~s} \mathrm{UT}$ ( 15.6 to $16.2 \mathrm{~km}, 216 \mathrm{~s}$ ) and for a total time of $9 \mathrm{~min}$. Cirrus were absent at temperatures above $T_{\text {ICE. }}$ The cirrus observations are indicated by thick gray lines in Fig. 1. The flight path in Fig. 1 in northerly direction was chosen to coincide with a Cloud-Aerosol Lidar and Infrared Pathfinder Satellite Observations (Calipso) overpass. Patchy cirrus clouds were also detected by the Calipso lidar, while particle volume and size of the $\mathrm{NO}_{\mathrm{y}}$ containing particle 


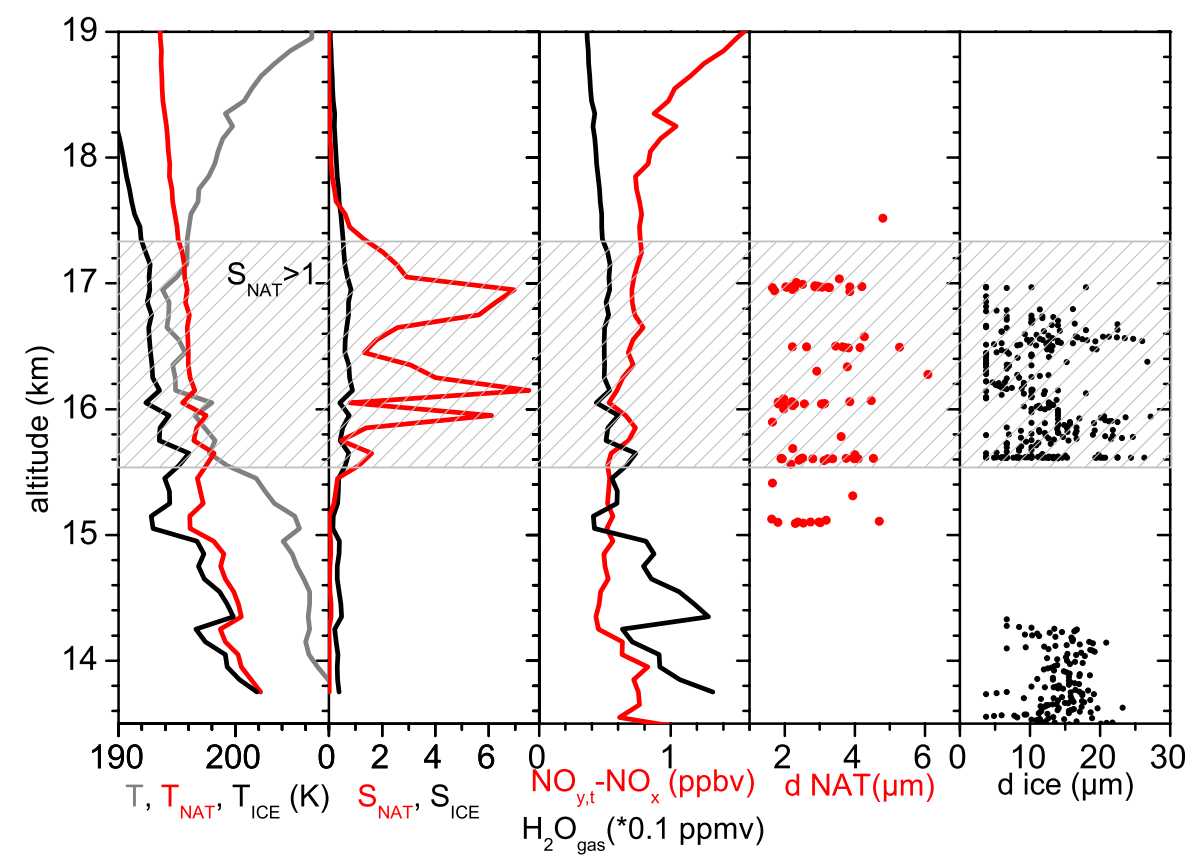

Fig. 3. Vertical mean profiles of $T, T_{\mathrm{NAT}}, T_{\mathrm{ICE}}, S_{\mathrm{NAT}}, S_{\mathrm{ICE}}, \mathrm{H}_{2} \mathrm{O}_{\mathrm{g}}$ and $\mathrm{NO}_{\mathrm{y}, \mathrm{t}}-\mathrm{NO}_{\mathrm{x}}$ as proxy for $\mathrm{HNO}_{3}$, NAT particle diameters detected with the $\mathrm{NO}_{\mathrm{y}}$ instrument and effective ice crystal diameters detected with the FSSP. The shaded area indicates a layer between 15.5 and $17.3 \mathrm{~km}$ altitude that is supersaturated with respect to NAT. Patchy cirrus clouds are observed below and embedded in the $2.4 \mathrm{~km}$ thick NAT particle layer.

layer are too low to allow for a detection from satellite. In addition, iridescent cirrus patches similar to ice PSCs were visually observed by scientists onboard the DLR Falcon flying nearby the Geophysica, in contrast the small and dilute $\mathrm{NO}_{\mathrm{y}}$ containing particles are not visible.

\section{NAT particle composition}

In our study, we analyze the sequence of peaks in the $\mathrm{NO}_{\mathrm{y}, \mathrm{t}}$ signal. These peaks were detected in the temperature range between 190.5 and $205.8 \mathrm{~K}$ at altitudes between 15.1 and $17.5 \mathrm{~km}$ as shown in Fig. 3. The particle layer was observed at temperatures down to $2.3 \mathrm{~K}$ below $T_{\mathrm{NAT}}$ and above $T_{\mathrm{ICE}}$. The NAT equilibrium temperature $T_{\mathrm{NAT}}$ and the NAT saturation ratio $S_{\mathrm{NAT}}$, that is the $\mathrm{HNO}_{3}$ vapor pressure divided by the $\mathrm{HNO}_{3}$ partial pressure over NAT, were calculated with Hanson and Mauersberger (1988) based on the detected temperature, $\mathrm{H}_{2} \mathrm{O}_{\mathrm{g}}$ and $\mathrm{HNO}_{3, \mathrm{t}}$ concentrations. Using $\mathrm{HNO}_{3, \mathrm{t}}$ instead of $\mathrm{HNO}_{3, \mathrm{~g}}$ in the formulation of Hanson and Mauersberger (1988) may introduce negligible errors of less than $0.1 \%$ in the derivation of $T_{\mathrm{NAT}}$.

An $8 \mathrm{~min}$ flight sequence from $44826 \mathrm{~s}$ UT at the lowest flight level of $15.1 \mathrm{~km}$ within the particle layer will be explained in detail later, as this region was strongly NAT subsaturated. In the remaining 74 min of particle detection, $\mathrm{NO}_{\mathrm{y}}$ containing particle were observed in the temperature range $T_{\mathrm{NAT}}-2.3 \mathrm{~K}$ to $T_{\mathrm{NAT}}+3.2 \mathrm{~K}$ and up to $T_{\mathrm{ICE}}+5.5 \mathrm{~K}$.
Give the measured super-saturation with respect to NAT and sub-saturation with respect to ice, we can assume NAT particle composition for the observed particle peaks and derive a particle diameter from the relationship $\mathrm{d}[\mu \mathrm{m}]=4.7 /\left[\Delta \mathrm{NO}_{\mathrm{y}, \mathrm{t}}\right]^{0.333}$ with $\left[\Delta \mathrm{NO}_{\mathrm{y}}\right]=\mathrm{NO}_{\mathrm{y}}\left(t_{\text {peak }}\right)-$ $\mathrm{NO}_{\mathrm{y}}\left(t_{\text {peak-1 s }}\right)$ in ppbv*sec (Northway et al., 2002). The residence of a particle/gas sample in the instrument is $\ll 1 \mathrm{~s}$ with the result that the $\mathrm{HNO}_{3}$ on a single particle is detected within the $1 \mathrm{~s}$ instrument integration period. We analyze peaks with a $\left[\Delta \mathrm{NO}_{\mathrm{y}}\right]>0.08 \mathrm{ppbv}^{*} \mathrm{sec}$ corresponding to NAT particles with $\mathrm{d}>1.8 \mu \mathrm{m}$. The particle sizes in the particle layer are depicted in Fig. 4. From the sum of particle observations, we derive a NAT particle number density $\mathrm{n}_{\mathrm{NAT}} \sim 3 \times 10^{-5} \mathrm{~cm}^{-3}$ for the diameter range $1.8<\mathrm{d}_{\mathrm{NAT}}<6.4 \mu \mathrm{m}$ corresponding to a particulate $\mathrm{HNO}_{3}$ content of a few pptv. The FSSP observed 4 particles in the diameter range between 2.7 and $5.4 \mu \mathrm{m}$ in flight segment A (see Fig. 1), yielding a particle number density of $\mathrm{n}_{\mathrm{NAT}} \sim 1.5 \times 10^{-5} \mathrm{~cm}^{-3}$, in agreement with the observations from the $\mathrm{NO}_{\mathrm{y}}$ instrument.

The particles producing these peaks are unlikely to be composed of a supercooled ternary solution (STS) of $\mathrm{H}_{2} \mathrm{O}$, $\mathrm{H}_{2} \mathrm{SO}_{4}$ and $\mathrm{HNO}_{3}$. Model calculations of the $\mathrm{HNO}_{3}$ partitioning between the gas and the liquid aerosol phase at low temperatures are presented in Voigt et al. (2007). Popp et al. (2007) show that the uptake of $\mathrm{HNO}_{3}$ in background sulphate aerosol is not thermodynamically favorable at above 


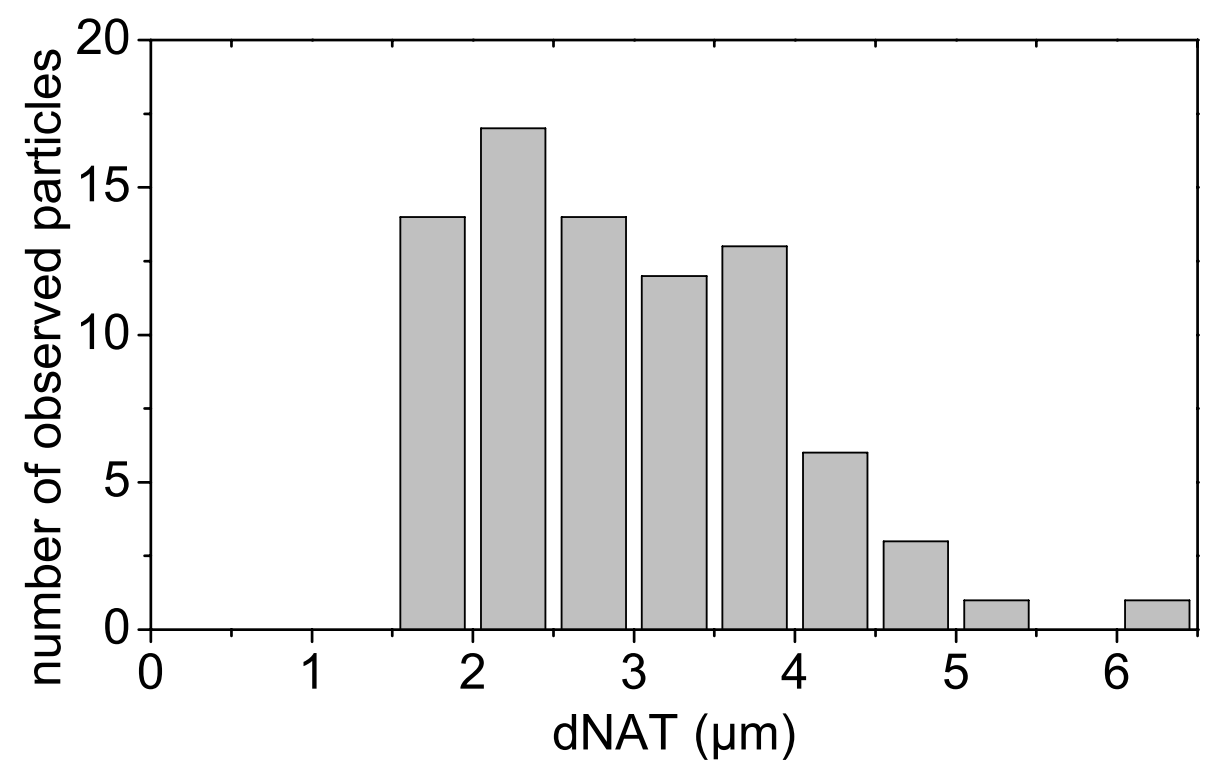

Fig. 4. Number of NAT particles observed in the individual size intervals inferred from the $\mathrm{NO}_{\mathrm{y}}$ data during the flight on 8 August 2006. Particles with $\mathrm{d}<1.8 \mu \mathrm{m}$ cannot be detected by the $\mathrm{NO}_{\mathrm{y}}$ instrument. The NAT particles yield a number density of $3 \times 10^{-5} \mathrm{~cm}^{-3}$.

$T_{\mathrm{NAT}}-4 \mathrm{~K}$ near the tropical tropopause. Also all available sulphate particles would grow by the uptake of $\mathrm{HNO}_{3}$, as there is no nucleation barrier for $\mathrm{HNO}_{3}$ uptake in liquid aerosol. Hence the STS particle concentration would be near the background particle concentrations $\left(\sim 10 \mathrm{~cm}^{-3}\right)$ and cannot explain the peaks in the $\mathrm{NO}_{\mathrm{y}, \mathrm{t}}$ signal, but only a smooth signal behavior.

In addition, the particle observations are unlikely to be composed of $\mathrm{HNO}_{3}$ contained in ice. First of all, the total and gas phase water data agree within the instrumental uncertainties in the time period between $44520 \mathrm{~s}$ UT and $47726 \mathrm{~s} \mathrm{UT}$, where $\mathrm{HNO}_{3}$ containing particles were observed. This suggests that ice particles were not present. In contrast, the observations of $\mathrm{HNO}_{3}$ in ice at similar and even lower temperatures during the TROCCINOX and the CR-AVE missions (Voigt et al., 2007; Popp et al., 2007) show a clear total water and FSSP signal. While total water, FSSP, backscatter and lidar data indicate the sporadic presence of patches of cirrus clouds, the $\sim 3 \mathrm{~km}$ thick layer of $\mathrm{HNO}_{3}$ containing particles was continuously observed at low temperatures near and below the tropopause.

It is unlikely, that the observed particles are mainly composed of Saharian desert dust. First of all, mineral dust has never been detected at altitudes up to $18 \mathrm{~km}$ right above its source region. Further, $\mathrm{HNO}_{3}$ reacting with mineral dust particles is typically solid, e.g. $\mathrm{HNO}_{3}$ (gas) $+\mathrm{CaCO}_{3}(\mathrm{~s})$ $\rightarrow \mathrm{Ca}\left(\mathrm{NO}_{3}\right)_{2}(\mathrm{~s})+\mathrm{H}_{2} \mathrm{O}+\mathrm{CO}_{2}$. This reaction represents a nearly permanent sink for $\mathrm{HNO}_{3}$ on dust particles. The solid particle nitrate will not return into the gas phase in the heated converter of the $\mathrm{NO}_{\mathrm{y}}$ instrument and will not be detected. Still we cannot completely exclude nitrate on mineral dust as the reaction with aluminosilicate $\left(\mathrm{Al}_{2} \mathrm{O}_{3}\right)$ leads to less stable surface nitrate that could indeed be thermally decomposed fairly easily.

It has been shown that biomass burning emissions could modify the composition of the TTL in the observation region (Mari et al., 2007) and therefore might contribute the detected high $\mathrm{HNO}_{3}$ concentrations (see Fig. 3). Considering NAT particle sizes up to $6 \mu \mathrm{m}$ and their presence connected to NAT supersaturation, it is unlikely, that the observed particles are biomass burning aerosol. Still, biomass burning emissions could provide condensation nuclei for NAT nucleation and partially explain high $\mathrm{HNO}_{3}$ concentrations that help to sustain NAT particle growth.

The supersaturation with respect to NAT, large $\mathrm{d}_{\mathrm{NAT}}<6 \mu \mathrm{m}$ and low particle concentrations $\mathrm{n}_{\mathrm{NAT}}<10^{-4} \mathrm{~cm}^{-3}$ all suggest that the particles were primarily composed of NAT.

\section{Conditions in the African TTL and NAT saturation}

As a first estimate, we used the measured $\mathrm{H}_{2} \mathrm{O}, \mathrm{HNO}_{3, \mathrm{t}}$ and temperature to derive mean profiles of $S_{\mathrm{NAT}}, S_{\mathrm{ICE}}$ in the observation region. As $\mathrm{HNO}_{3}$ uptake in STS aerosol is not thermodynamically favorable at temperatures above $T_{\mathrm{NAT}}-4 \mathrm{~K}$, we can neglect the nitrate content in aerosol and use $\mathrm{HNO}_{3, \mathrm{t}}$ as upper limit for $\mathrm{HNO}_{3, \mathrm{~g}}$. We note that $\mathrm{HNO}_{3}$ concentrations between 0.4 and $1 \mathrm{ppbv}$ in the African TTL are significantly higher than $\mathrm{HNO}_{3}$ concentrations of 0.1 to $0.2 \mathrm{ppbv}$ observed at $18 \mathrm{~km}$ altitude under remote conditions over the eastern Pacific (Popp et al., 2006). Transport and processing of nitrogen oxide rich biomass burning plumes from lower 

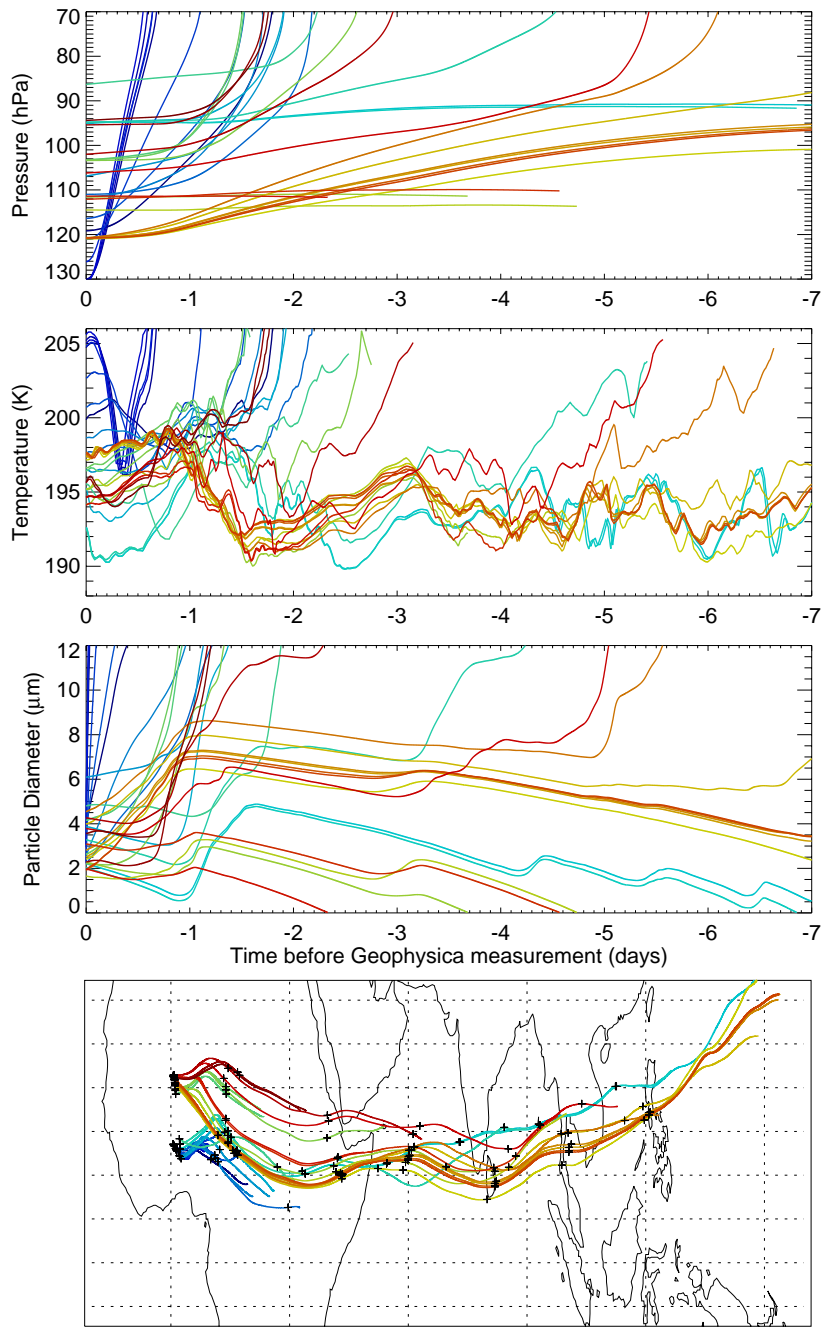

Fig. 5. Particle back trajectories are shown for a representative subset of the NAT particles sampled. Particle location, size, and height are tracked backwards in time from the observation locations. Panels show: (a) particle pressure, (b) temperature, (c) diameter, and (d) geographic location. See text for details.

latitudes and subsequent lifting of the emissions in convectively active regions (Mari et al., 2007) could partially explain to the observed high $\mathrm{HNO}_{3}$ concentrations in the TTL. In addition, nitrogen oxides from lightning in convective regions east of the observation area could contribute to the observed enhanced $\mathrm{HNO}_{3}$ concentrations in the TTL.

While most of the NAT particle layer was detected under NAT supersaturated conditions, mainly the particles below $15.8 \mathrm{~km}$ encountered conditions near NAT saturation $\left(S_{\mathrm{NAT}} \cong 1\right)$ and at the lowest level $(15.1 \mathrm{~km})$ particles were even observed at $S_{\mathrm{NAT}} \ll 1$ (see Fig. 3). Uncertainties in the temperature and the observed $\mathrm{H}_{2} \mathrm{O}$ and $\mathrm{HNO}_{3, \mathrm{t}}$ concentrations may explain the presence of NAT particles under slightly sub-saturated conditions $\left(S_{\mathrm{NAT}} \leq 1\right)$. Further and even more important, it requires few days for a $5 \mu \mathrm{m}$ NAT parti- cle to sublimate at $2 \mathrm{~K}$ above $T_{\mathrm{NAT}}$. The NAT particles near $15.1 \mathrm{~km}$ altitude have been observed right after descending though a cirrus cloud (near $44500 \mathrm{~s}$ in Fig. 2), suggesting that $\mathrm{HNO}_{3}$ containing ice (or NAT) particles could have sedimentated out of the cirrus region. In ice sub-saturated conditions below the cirrus cloud, the ice particles will evaporate and could potentially release a NAT particle which slowly sublimates.

Summarized, based on the combined evidence, we suggest that the Geophysica probed a tropical NAT particle layer in the African TTL. Total $\mathrm{NO}_{\mathrm{y}}$, hence the composition of NAT particles, has only been measured on 8 August 2006. Still, the FSSP detected low concentrations $\left(<10^{-4} \mathrm{~cm}^{-3}\right)$ of small particles $(\mathrm{d}<5 \mu \mathrm{m})$ on every flight in the West African TTL, suggesting that this category of particles is ubiquitous in the tropical tropopause layer. While the observations of NAT particles in the tropics are rare, dilute concentrations of NAT particles were frequently detected in the late polar winter stratosphere (Fahey et al., 2001; Northway et al., 2002). Still, many years after their discovery, the nucleation process of polar stratospheric NAT particles remains uncertain. Hence we study NAT particle nucleation, growth and transport in the tropics to gain insight in NAT nucleation processes in different regions of the atmosphere.

\section{NAT growth and transport}

In order to evaluate the plausibility of in situ growth and transport of the NAT particles in the TTL, we have calculated particle back trajectories using interpolated ECMWF wind and temperature fields. Starting at the times and locations where the particles were observed, we integrate backwards in time tracking the size, geographical location, and height (including sedimentation) of each particle. The ECMWF temperatures are adjusted based on the Geophysica temperature measurements at the locations where the particles were sampled. Since we are integrating backwards in time, the particles rise (due to sedimentation) and shrink (due to deposition growth in NAT supersaturated air) as the calculation proceeds. The analysis vertical winds are not used because of excessive noise, and instead we impose a slow upwelling $\left(0.3 \mathrm{~mm} \mathrm{~s}^{-1}\right)$ corresponding to the radiatively balanced ascent in the TTL. Vertical profiles of the NAT saturation ratio are calculated based on mean profiles of $\mathrm{H}_{2} \mathrm{O}_{\mathrm{t}}$ and $\mathrm{HNO}_{3, \mathrm{t}}$ observed with the Geophysica on 8 August 2008. If the particles shrink to zero diameter before ascending into NAT subsaturated air in the stratosphere, we argue that the calculation supports NAT growth within the TTL. If the particles reach sub-saturated air above the tropopause, there tends to be a rapid feedback of increasing size (caused by sublimation in reverse time) and faster ascent into more sub-saturated air.

As shown in Fig. 5, at least some of the particles could very well have resulted from in situ growth, transport, and sedimentation within the TTL. The results from these 


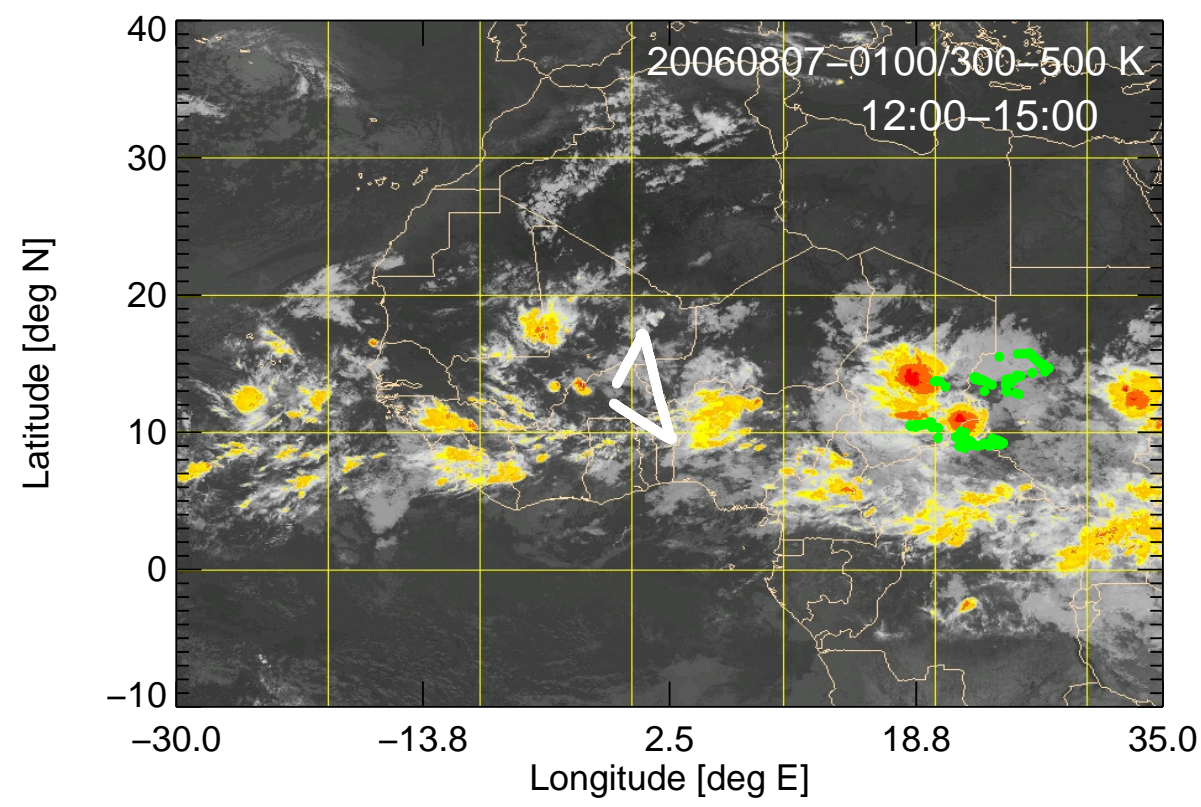

Fig. 6. Location of trajectories (green lines) ending about 1.5 days later on the flight track (white line) near the NAT observation regions; superposed to MSG - Meteosat Second Generation brightness temperatures on 7 August at 01:00 UT (red 195 K, orange 210 K, yellow $225 \mathrm{~K}$ ). The MSG data show that the African TTL was influenced by convection for more than 1.5 days prior to the measurements.

calculations are very insensitive to the assumed water vapor mixing ratio and upwelling speed. If the TTL $\mathrm{HNO}_{3}$ concentrations were well below the values assumed here $(\simeq 0.5-$ $1 \mathrm{ppbv})$, then in situ growth of the NAT particles would likely not have been possible.

There is considerable uncertainty in the analysis temperature fields, particularly in the tropics where radiosondes are scarce. If we further decrease the temperature by $2 \mathrm{~K}$, then the in situ growth of most of the particles can be explained except for a subset of the particles that was sampled at pressures of $125-130 \mathrm{hPa}$ in extremely NAT sub-saturated air (blue colors in Fig. 5). The latter subset of particles grow and ascend through the TTL very rapidly in the reverse-time calculations. For example, the particles sampled at sampled at $130 \mathrm{hPa}$ grow to $12 \mu \mathrm{m}$ within $6 \mathrm{~h}$ and ascend well into the stratosphere within about $12 \mathrm{~h}$. As a result, it does not seem possible that these particles formed as a result of in situ nucleation and growth in the tropopause region. These particles give hints for the particle nucleation mechanism as discussed below.

\section{NAT nucleation}

Various NAT nucleation pathways have been suggested to explain low number density NAT particle observations in the polar stratosphere, such as NAT nucleation on meteoritic material (Voigt et al., 2005), other solid inclusions (Bogdan et al., 2003) or NAT nucleation aided by cosmic rays (Carslaw et al., 2002). In addition, NAT nucleation on ice,
E39C-A, 89 hPa, annual mean (2000 - 2004)

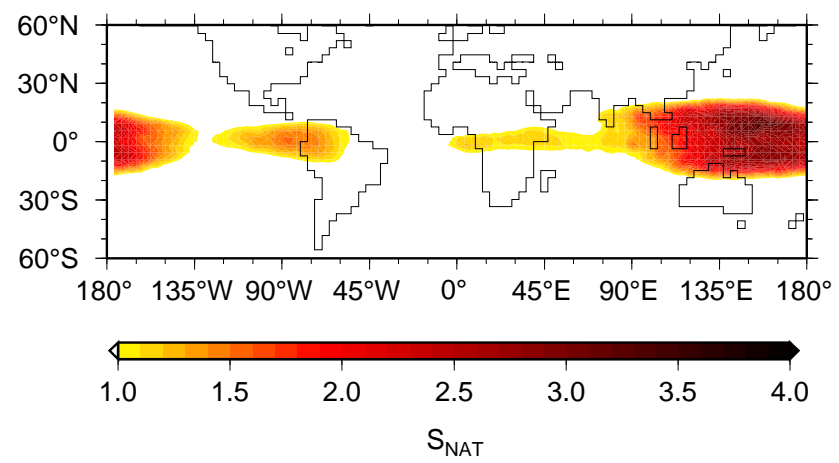

Fig. 7. Annual mean NAT saturation ratio $S_{\mathrm{NAT}}$ at $89 \mathrm{hPa}$ as calculated with the global chemistry climate model E39C-A. See text for further details. The results show the potential for a global tropical tropopause NAT belt.

ice sedimentation and evaporation and subsequent release of NAT particles has been shown to explain low concentrations of NAT particle populations in the Arctic stratosphere (Fueglistaler et al., 2002a,b; Dhaniyala et al., 2002; Voigt et al., 2000, 2003) to some extent. We suggest that a similar process could occur in the tropics.

Cloud top brightness temperature data from the Meteosat Second Generation MSG satellite show that the TTL was influenced by convection (Fig. 6). Backtrajectories starting on the flight track in the NAT observation regions are located above a mesoscale convective system for at least 1.5 days 
prior to the measurements with cloud top levels up to at least $120 \mathrm{hPa}(\sim 16 \mathrm{~km}$ altitude), suggesting that ice crystals could have been injected into the TTL by convective overshoots or could have formed in-situ caused by gravity waves above the convectively active region. Patchy cirrus were observed during the flight on 8 August 2006 imbedded in the extended NAT particle layer. Our estimates show that despite $S_{\mathrm{NAT}}<8$ in our case, deposition nucleation on ice as suggested by Luo et al. (2003) could provide a potential pathway for NAT nucleation under conditions prevailing in the African tropical tropopause region. While we cannot completely exclude other nucleation processes, it seems likely that the NAT particles nucleated on ice and that the NAT particle observation regions were influenced by convection. Sedimentation and release of NAT particles from evaporating cirrus clouds could also explain the particle layer, that was sampled under NAT sub-saturated conditions at pressures of $125-130 \mathrm{hPa}$ right after the detection of a cirrus cloud about $0.5 \mathrm{~km}$ above.

\section{The tropical tropopause NAT belt}

Our observations suggest that NAT particles could routinely be present in the tropical transition layer. To explore this idea, we used the chemistry-climate model ECHAM4L39(DLR)/CHEM/ATTILA (E39C-A) to calculate the NAT saturation ratio near the tropical tropopause. The CCM E39C-A is an updated version of the E39C model (Dameris et al., 2005) employing the fully Lagrangian advection scheme ATTILA (Reithmeier and Sausen, 2002) for the transport of water vapor, cloud water and chemical trace species. Improvements in model dynamics resulting from Lagrangian water vapor transport have been extensively described by Stenke et al. (2008). The present model results of E39C-A are based on a transient simulation of the time period from 1960 to 2004 following the experimental set-up of Dameris et al. (2005).

We calculated $S_{\text {NAT }}$ at the $89 \mathrm{hPa}$ level using Hanson and Mauersberger (1988) from 12 hourly (00:00 and 12:00 UTC) modeled temperatures, $\mathrm{HNO}_{3}$ and $\mathrm{H}_{2} \mathrm{O}$ fields. While cloud formation is allowed in the model simulation, the nucleation and growth of NAT particles is not considered between $40^{\circ} \mathrm{N}$ and $40^{\circ} \mathrm{S}$ latitude, because dilute NAT particle concentrations $\left(\mathrm{n}<10^{-4} \mathrm{~cm}^{-3}\right)$ do not significantly denitrify the TTL. Still the model comparison to observed $\mathrm{NO}_{\mathrm{y}}$ profiles during the SCOUT-O3/AMMA campaign show, that the model underestimates mean observed $\mathrm{NO}_{\mathrm{y}}$ concentrations. Fig. 6 shows the annual mean $S_{\mathrm{NAT}}$ for the years 2000 to 2004 . Regions with high $S_{\mathrm{NAT}}$ reflect regions with low temperatures as for example related to the Indonesian cold pool. The modeled NAT saturation ratio near the tropical tropopause has an annual cycle with highest values of more than 6 in January and lowest values in July/August. More than $82 \%$ of the $89 \mathrm{hPa}$ level between $5^{\circ} \mathrm{N}$ and $5^{\circ} \mathrm{S}$ is supersaturated with respect to NAT. Further our trajectory calculations show that small NAT particles can remain in the TTL for days under NAT saturated conditions. Combined our results show frequent conditions for the presence of NAT particles in the TTL.

\section{Conclusions}

Dilute populations of NAT particles have been measured in the tropical transition layer with the $\mathrm{NO}_{\mathrm{y}}$ instrument onboard the high altitude research aircraft M55-Geophysica. This unique detection of a NAT particle layer over the African continent extends the observation range of NAT particles to the tropical upper troposphere. It seems plausible that the NAT particles nucleated on ice influenced by convection. Hence our observations suggest a similar nucleation process for tropical and polar NAT particles.

The combination of NAT particle observations in the TTL, NAT growth and transport calculations within the TTL and global model results of NAT saturated regions show the potential for the presence of a tropical tropopause NAT belt, characterized by moderate NAT supersaturation, the frequent presence of NAT particles and long-range NAT particle transport. While the detection of NAT particles in the TTL consolidates the picture of NAT particle formation in different regions of the atmosphere, further observations are needed to better understand the details of the NAT nucleation mechanism.

Acknowledgements. The M55-Geophysica AMMA-SCOUT campaign in West Africa was funded by the Geophysica EEIG, French CNRS-INSU/CNES and European Community sixth framework integrated projects SCOUT-O3 (505390-GOCE-CT-2004) and AMMA-EU. Based on a French initiative, AMMA was built by an international scientific group and is currently funded by a large number of agencies, especially from France, UK, US and Africa. It has been the beneficiary of a major financial contribution from the European Community's Sixth Framework Research Programme. CV performed part of the work within the Junior Research Group AEROTROP and MdR acknowledges the support through the SFB641:TROPICE. We thank B. Luo, B. Kärcher, D. Fahey and T. Peter for fruitfull discussions. The Geophyisca crew is acknowledged for excellent flight operation and K. Law and F. Cairo for the coordination of the Geophysica campaign. The global model simulations have been performed on the NEC SX-6 high performance computer of the German Computing Centre (DKRZ). ECMWF data were provided by the European Centre for Medium Range Weather Forecasts.

Edited by: M. Ammann 


\section{References}

Bogdan, A., Molina, M. J., Kulmala, M., MacKenzie, A. R., and Laaksonen, A.: Study of finely divided aqueous systems as an aid to understanding the formation mechanism of polar stratospheric clouds: Case of $\mathrm{HNO}_{3} / \mathrm{H}_{2} \mathrm{O}$ and $\mathrm{H}_{2} \mathrm{SO}_{4} / \mathrm{H}_{2} \mathrm{O}$ systems, J. Geophys. Res., 108(D10), 4302, doi:10.1029/2002JD002605, 2003.

Borrmann, S., Solomon, S., Dye, J. E., and Luo, B.: The potential of cirrus clouds for heterogeneous chlorine activation, Geophys. Res. Lett., 23(16), 2133-2136, doi:10.1029/96GL01957, 1996.

Borrmann, S., Thomas, A., Rudakov, A., Yushkov, V., Lepuchov, B., Deshler, T., Vinnichenko, N., Khattatov, V., and Stefanutti, L.: In-situ measurements in the Northern hemispheric stratosphere of the 1996/1997 winter on the Russian M-55 Geophysica high altitude research aircraft, Tellus, 52B, 1088-1103, 2000.

Carslaw, K. S., Kettleborough, J. A., Northway, M. J., et al.: A vortex-scale simulation of the growth and sedimentation of large nitric acid hydrate particles, J. Geophys. Res., 107(D20), 8300, doi:10.1029/2001JD000467, 2002.

Carslaw, K. S., Harrison, R. G., and Kirkby, J.: Cosmic rays, clouds and climate, Science, 298, 1732-1737, 2002.

Chepfer H., Minnis, P., Dubuisson, P., Chiriaco, M., Sun-Mack, S., and Rivière, E. D.: Nitric acid particles in cold thick ice clouds observed at global scale: Link with lightning, temperature, and upper tropospheric water vapor, J. Geophys. Res., 112, D05212, doi:10.1029/2005JD006602, 2007.

Dhaniyala, S., Mckinney, K. A., and Wennberg, P. O.: Lee-wave clouds and denitrification of the polar stratosphere, Geophys. Res. Lett., 29(9), 1322, doi:10.1029/2001GL013900, 2002.

Dameris, M., Grewe, V., Ponater, M., Deckert, R., Eyring, V., Mager, F., Matthes, S., Schnadt, C., Stenke, A., Steil, B., Brhl, C., and Giorgetta, M. A.: Long-term changes and variability in a transient simulation with a chemistry-climate model employing realistic forcing, Atmos. Chem. Phys., 5, 2121-2145, 2005, http://www.atmos-chem-phys.net/5/2121/2005/.

Davies, S., Mann, G. W., Carslaw, K. S., Chipperfield, M. P., Kettleborough, J. A., Santee, M. L., Oelhaf, H., Wetzel, G., Sasano, Y., and Sugita, T.: 3-D microphysical model studies of Arctic denitrification: comparison with observations, Atmos. Chem. Phys., 5, 3093-3109, 2005, http://www.atmos-chemphys.net/5/3093/2005/.

Fahey, D. W., Gao, R. S., Carslaw, K. S., et al.: The detection of large $\mathrm{HNO}_{3}$-containing particles in the winter arctic stratosphere, Science, 291, 1026-1031, 2001.

Fueglistaler, S., Luo, B. P., Voigt, C., Carslaw, K. S., and Peter, T.: NAT-rock formation by mother clouds: a microphysical model study, Atmos. Chem. Phys., 2, 93-98, 2002, http://www.atmos-chem-phys.net/2/93/2002/.

Fueglistaler, S., Luo, B. P., Voigt, C., Carslaw, K. S., and Peter, T.: Large NAT formation by mother clouds: Analysis of SOLVE/THESEO-2000 observations, Geophys. Res. Lett., 29(12), doi:10.1029/2001GL14548, 2002.

Gao, R. S., Popp, P. J., Fahey, D. W., Marcy, T. P., Herman, R. L., Weinstock, E. M., Baumgardner, D. G., Garrett, T. J., Rosenlof, K. H., Thompson, T. L., Bui, T. P., Ridley, B. A., Wofsy, S. C., Toon, O. B., Tolbert, M. A., Kärcher, B., Peter, T., Hudson, P. K., Weinheimer, A. J., and Heymsfield, A. J.: Evidence that ambient nitric acid increases relative humidity in low-temperature cirrus clouds, Science, 303, 516-520, 2004.
Hamill, P. and Fiocco, G.: Nitric acid aerosols at the tropical tropopause, Geophys. Res. Lett., 15, 1189-1192, 1988.

Hanson, D. and Mauersberger. K.: Laboratory studies of the nitric acid trihydrate: Implications for the south polar stratosphere, Geophys. Res. Lett., 15, 855-858, 1988.

Hervig, M. and McHugh, M.: Tropical nitric acid clouds, Geophys. Res. Lett., 29(7), 1125, doi:10.1029/2001GL014271, 2002.

Jensen, E. and Drdla, K.: Nitric acid concentrations near the tropical tropopause: Implications for the properties of nitric acid trihydrate clouds, Geophys. Res. Lett., 29(20), 2001, doi:10.1029/2002GL015190, 2002.

Kärcher, B. and Voigt, C.: Formation of nitric acid/water ice particles in cirrus clouds, Geophys. Res. Lett., 33, L08806, doi:10.1029/2006GL025927, 2006.

Luo, B. P., Voigt, C., Fueglistaler, S., and Peter, T.: Extreme NAT supersaturations in mountain wave ice PSCs: A clue to NAT formation, J. Geophys. Res., 108(D15), 4441, doi:10.1029/2002JD003104, 2003.

Mari, C. H., Cailley, G., Corre, L., Saunois, M., Attié, J. L., Thouret, V., and Stohl, A.: Tracing biomass burning plumes from the Southern Hemisphere during the AMMA 2006 wet season experiment, Atmos. Chem. Phys. Discuss., 7, 17339-17366, 2007 , http://www.atmos-chem-phys-discuss.net/7/17339/2007/.

Marti, J. and Mauersberger, K.: A survey and new measurements of ice vapor pressure at temperatures between 170 and $250 \mathrm{~K}$, Geophys. Res. Lett., 20, 363-366, 1993.

Northway, M. J., Gao, R. S., Popp, P. J., et al.: An analysis of large $\mathrm{HNO}_{3}$-containing particles sampled in the Arctic stratosphere during the winter of 1999/2000, J. Geophys. Res., 107(D20), 8298, doi:10.1029/2001JD001079, 2002.

Popp, P. J., Gao, R. S., Marcy, T. P., Fahey, D. W., Hudson, P. K., Thompson, T. L., Kärcher, B., Ridley, B. A., Weinheimer, A. J., Knapp, D. J., Montzka, D. D., Baumgardner, D. G., Garrett, T. J., Weinstock, E. M., Smith, J. B., Sayres, D. S., Pittman, J. V., Dhaniyala, S., Bui, T. P., and Mahoney, M. J.: Nitric acid uptake on subtropical cirrus cloud particles, J. Geophys. Res., 109, D06302, doi:10.1029/2003JD004255, 2004.

Popp, P. J., Marcy, T. P., Jensen, E. J., Kärcher, B., Fahey, D. W., Gao, R. S., Thompson, T. L., Rosenlof, K. H., Richard, E. C., Herman, R. L., Weinstock, E. M., Smith, J. B., May, R. D., Vömel, H., Wilson, J. C., Heymsfield, A. J., Mahoney, M. J., and Thompson, A. M.: The observation of nitric acid-containing particles in the tropical lower stratosphere, Atmos. Chem. Phys., 6, 601-611, 2006, http://www.atmos-chem-phys.net/6/601/2006/.

Popp, P. J., Marcy, T. P., Watts, L. A., Gao, R. S., Fahey, D. W., Weinstock, E. M., Smith, J. B., Herman, R. L., Troy, R. F., Webster, C., Christensen, L. E., Baumgardner, D. G., Voigt, C., Kärcher, B., Wilson, J. C., Mahoney, M. J., Jensen, E. J., and Bui, T. P.: Condensed-phase nitric acid in a tropical subvisible cirrus clouds, Geophys. Res. Lett., 34, L24812, doi:10.1029/2007GL031832, 2007.

Reithmeier, S. and Sausen, R.: ATTILA: Atmospheric Tracer Transport in a Lagrangian Model, Tellus, 54(B), 278-299, 2002.

Schiller, C., Afchine, A., Eicke, N., Feigl, C., Fischer, H., Giez, A., Konopka, P., Schlager, H., Tuitjer, F., Wienhold, F. G., and Zöger, M.: Ice particle formation and sedimentation in the tropopause region: A case study based on in situ measurements of total water during POLSTAR 1997, Geophys. Res. Lett., 26, 2219-2222, 
doi:10.1029/1999GL900337, 1999.

Stenke, A., Grewe, V., and Ponater, M.: Lagrangian transport of water vapour and cloud water in the ECHAM4 GCM and its impact on the cold bias, 31, 491-506, doi:10.1007/s00382-007-0347-5, 2008.

Voigt, C., Schreiner, J., Kohlmann, A., Zink, P., Mauersberger, K., Larsen, N., Deshler, T., Krger, C., Rosen, J., Adriani, A., Cairo, F., Di Donfrancesco, G., Viterbini, M., Ovarlez, J., Ovarlez, H., David, C., and Dörnbrack, A.: Nitric Acid Trihydrate (NAT) in Polar Stratospheric Clouds, Science, 290, 1756-1758, 2000.

Voigt, C., Larsen, N., Deshler, T., Kröger, C., Schreiner, J., Mauersberger, K., Luo, B., Adriani, A., Cairo, F., Di Donfrancesco, G., Ovarlez, J., Ovarlez, H., Dörnbrack, A., Knudsen, B., and Rosen, J.: In situ mountain-wave polar stratospheric cloud measurements, J. Geophys. Res., 108(D15), 8331, doi:10.1029/2001JD001185, 2003.
Voigt, C., Schlager, H., Luo, B. P., Dörnbrack, A., Roiger, A., Stock, P., Curtius, J., Vössing, H., Borrmann, S., Davies, S., Konopka, P., Schiller, C., Shur, G., and Peter, T.: Nitric Acid Trihydrate (NAT) formation at low NAT supersaturation in Polar Stratospheric Clouds (PSCs), Atmos. Chem. Phys., 5, 13711380, 2005, http://www.atmos-chem-phys.net/5/1371/2005/.

Voigt, C., Schlager, H., Ziereis, H., Kärcher, B., Luo, B. P., Schiller, C., Krämer, M., Popp, P. J., Irie, H., and Kondo, Y.: Nitric acid uptake in cirrus clouds, Geophys. Res. Lett., 33, L05803, doi:10.1029/2005GL025159, 2006.

Voigt, C., Kärcher, B., Schlager, H., Schiller, C., Krämer, M., de Reus, M., Vössing, H., Borrmann, S., and Mitev, V.: In-situ observations and modeling of small nitric acid-containing ice crystals, Atmos. Chem. Phys., 7, 3373-3383, 2007,

http://www.atmos-chem-phys.net/7/3373/2007/. 